\title{
Model problem based learning dengan geospatial information: Implementasi dalam pembelajaran Geografi dengan untuk kemampuan spatial thinking
}

\author{
Yuni Kartika Sita Dewi, Budi Handoyo*, Purwanto \\ Universitas Negeri Malang, Jl. Semarang No. 5 Malang, Jawa Timur, Indonesia \\ *Penulis korespondensi, Surel: budi.handoyo.fis@um.ac.id
}

Paper received: 02-03-2021; revised: 15-03-2021; accepted: 30-03-2021

\begin{abstract}
Abstrak
Berpikir spasial lekat dengan geografi karena salah satu pendekatan geografi merupakan pendekatan keruangan (spasial). Kemampuan berpikir spasial menjadi penting karena setiap fenomena geografi yang dikaji mencakup suatu ruang yang mempengaruhi ruang lainnya. Kegiatan pembelajaran yang dapat membangun kemampuan berpikir spasial yaitu menggunakan model Problem Based Learning menggunakan informasi geospasial sebagai media. Penelitian ini bertujuan untuk mengetahui pengaruh model Problem Based learning menggunakan informasi geospasial terhadap kemampuan berpikir spasial siswa kelas X IIS di SMAN Bandarkedungmulyo Jombang. Rancangan penelitian ini menggunakan eksperimen semu pretest postest. Penelitian ini menggunakan instrumen berupa soal essaisebanyak 8 butir untuk mengukur kemampuan berpikir spasial. Hasil penelitian menunjukkan bahwa model Problem Based Learning menggunakan media informasi geospasial berpengaruh terhadap kemampuan berpikir spasial.
\end{abstract}

Kata kunci: geospasial; kemampuan berpikir spasial

\section{Pendahuluan}

Model Problem Based Learning (PBL) merupakan model pembelajaran yang berlandaskan kontruktivisme dan mengakomodasikan keterlibatan siswa dalam belajar serta terlibat dalam pemecahan masalah yang kontekstual. Untuk memperoleh informasi dan mengembangkan konsep-konsep sains, siswa belajar bagaimana membangun kerangka masalah, mencermati, mengumpulkan data, dan mengorganisasikan masalah, menyusun fakta, menganalisis data, dan menyusun argumentasi terkait pemecahan masalah, kemudian memecahkan masalah baik secara individual maupun berkelompok.

Menurut Trianto (2009) beberapa keunggulan yang dimiliki PBL yaitu (1) realistik dengan kehidupan siswa, (2) konsep sesuai dengan kehidupan siswa, (3) memupuk sifat inquiry siswa, (4) retensi konsep jadi kuat, (5) memupuk kemampuan problem solving siswa. Dari pernyataan Trianto tersebut, maka dapat diketahui bahwa PBL memiliki keunggulan secara teoritis dan memiliki keunggulan secara empiris. Menurut peneliti, secara teoritis model PBL memiliki keunggulan yaitu dapat memupuk sifat inquiry dan melatih siswa dalam memecahkan masalah. Sedangkan secara empiris, model PBL memiliki keunggulan yaitu siswa dapat terjun langsung ke lapangan dalam proses penyelidikan masalah secara nyata atau realistik dengan kehidupan siswa dan dapat mengembangkan kemampuan berpikir siswa. Adapun contoh empirisnya yaitu saat anak diminta menyelidiki masalah penyebab terjadinya longsor,maka anak akan berpikir dalam menganalisis atau menemukan solusi dari masalah tersebut sehingga kemampuan berpikir anak akan berkembang. Dengan demikian, model PBL memiliki dua keunggulan yaitu keunggulan teoritis dan empiris. Model pembelajaran Problem Based Learning (PBL) dipilih untuk dieksperimenkan karena memiliki beberapa alasan. Alasan 
tersebut terdiri dari: 1) PBL sesuai dengan pembelajaran yang diterapkan dalam Kurikulum K13; 2) meningkatkan keaktifan siswa; 3) Problem Based Learning (PBL) dapat mendorong siswa belajar secara kontekstual; 4) dan mengembangkan kemampuan berpikir.

Proses pembelajaran bermakna tak hanya mencari model yang tepat bagi kebutuhan peserta didik. Namun perlu adanya daya dukung dari media pembelajaran. Geografi sendiri merupakan ilmu yang abstrak, tidak semua siswa memiliki daya imajinasi yang bagus dan cukup hanya dijelaskan melaui ceramah. Beberapa siswa lebih memahami materi jika mereka melihat, bahkan melakukan praktik dalam pembelajaran. Bobbie DePorter dan Mike Hernacki dalam publikasinya yang terkenal berjudul Quantum Learning menyatakan bahwa belajar dapat terjadi dengan cara: 10\% dari apa yang kita baca, 20\% dari apa yang kita dengar, 30\% dari apa yang kita lihat, 50\% dari apa yang kita lihat dan dengar, 70\% dari apa yang kita lakukan, dan 90\% dari apa yang kita katakan dan lakukan (dalam Warsono dan Hariyanto, 2012). Jadi, kegiatan pembelajaran serta media yang dirancang guru mempengaruhi pemahaman yang diperoleh siswa. Maka dari itu, model serta media yang dibutuhkan saat kegiatan belajar perlu diselaraskan agar tercapainya tujuan pembelajaran.

Media pembelajaran merupakan salah satu komponen pembelajaran yang mempunyai peranan penting dalam kegiatan belajar mengajar. Pemanfaatan media seharusnya merupakan bagian yang harus mendapat perhatian guru dalam setiap kegiatan pembelajaran. Oleh karena itu guru perlu mempelajari bagaimana menetapkan media pembelajaran agar dapat mengefektifkan pencapaian tujuan pembelajaran dalam proses belajar mengajar.

Proses pembelajaran geografi menggunakan informasi geospasial sangatlah diperlukan untuk menunjang efektifitas proses belajar mengajar siswa. Geografi membahas fenomena yang terjadi di segala aspek keruangan. Membahas keruangan tanpa menghadirkannya di saat pembelajaran geografi akan membuat siswa sulit memahami sehingga akan menggangu proses analisis siswa. Tidak semua siswa memiliki kemampuan spasial yang baik, jika hanya berimajinasi dan membayangkan tentang aspek keruangan akan menyulitkan siswa dalam mengolah informasi. Maka dari itu diperlukan informasi geospasial sebagai media dalam pembelajaran geografi karena mencakup informasi segala aspek keruangan yang dibutuhkan.

Informasi geospasial dalam pengajaran geografi merupakan media belajar yang penting untuk mengembangkan pengertian ruang dan tempat. Informasi geospasial dapat digunakan untuk meminta atau membantu menjawab berbagai jenis pertanyaan spasial, mengembangkan keterampilan spasial dan meningkatkan kemampuan untuk berpikir secara spasial.Mengembangkan kemampuan berpikir spasial siswa membantu menumbuhkan keterampilan, pengetahuan, dan pemahaman geografis.

Geografi memiliki peran yang unggul dalam berurusan dengan hubungan antara manusia dengan ruang. Oleh karena itu geografi menjadi disiplin akademik yang paling cocok untuk membantu perkembangan kemampuan berpikir spasial melalui serangkaian kegiatan diktatik yang tepat (Sarno, 2012). Banyak siswa yang belajar geografi belum memiliki orientasi visual dan kemampuan berpikir spasial yang memadai. Pada umumnya konten geografi yang diajarkan pada siswa belum menekankan pada kemampuan berpikir spasial, meskipun pada kurikulum telah ada kompetensi inti yang memungkinkan untuk dilakukannya pembelajaran yang melatih kemampuan berpikir spasial. Padahal berpikir spasial merupakan bagian yang penting untuk memahami fenomena-fenomena geografi. 
Berpikir spasialmerupakan suatu pendekatan ataupun cara berpikir dengan menggunakan kesadaran ruang/ keruangan. Goodchild (2006) berpendapat bahwa pemikiran spasial adalah salah satu bentuk dasar kecerdasan yang dibutuhkan untuk berfungsi dalam masyarakat modern. Berpikir spasial sebagai keterampilan dasar dan esensial yang pembangunannya harus menjadi bagian dari pendidikan setiap orang, seperti belajar bahasa, berhitung dan matematika.

Berpikir spasial lekat dengan geografi karena salah satu pendekatan geografi merupakan pendekatan keruangan (spasial). Hal ini tentunya mengasah kemampuan siswa dalam menganalis suatu fenomena dari segi keruangan. Kemampuan berpikir spasial menjadi penting karena setiap fenomena geografi yang dikaji mencakup suatu ruang yang mempengaruhi ruang lainnya. Sehingga ketajaman berpikir spasial harus dikembangkan.

Berpikir spasial terbangun oleh tiga unsur utama, yaitu konsep ruang, alat merepresentasikan, dan proses penalaran. Seperti yang diungkapkan oleh National Research Council (2006). Dari pendapat tersebut dapat diartikan bahwa berpikir spasial adalah keterampilan memahami konsep ruang, alat representasi dan proses penalaran guna mendeskripsikan dan menganalisis pola keruangan akibat adanya interaksi manusia, tempat dan lingkungan. Dengan demikian, penggunaan informasi geospasial dapat memudahkan siswa dalam menganalisis pola keruangan.

Sejak National Academy of Sciences menerbitkan laporan yang berjudul "Learning to Think Spatially" (Committee on Support for Thinking Spatially, 2006), yang secara gamblang menunjukkan urgensi berpikir spasial dalam memecahkan berbagai masalah, strategi pembelajaran berpikir spasial di sekolah, peran teknologi spasial dalam upaya pengembangan kemampuan berpikir spasial. Kemampuan berpikir sapsial menjadi wacana yang menarik. Hubungan antara sains informasi geografis (GIScience) dan berpikir spasial telah menarik minat banyak para ahli geografi, seperti Goodchild, Golledge, Gersmehl \& Gersmehl, Lee, Bernadz dan lain-lain untuk melakukan kajian lebih lanjut. Para ahli tersebut meyakini bahwa pembelajaran geografi memiliki peran penting untuk berkontribusi dalam mengembangkan kemampuan berpikir spasial para peserta didik.

Berdasarkan pandangan yang telah disampaikan dalam paragraf sebelumnya mengenai perlunya berpikir spasial untuk dikembangkan dalampembelajaran geografi serta upaya mengembangkannya dibantu oleh media pembelajaran yang menggunakan informasi geospasial sebagai alat bantu menghadirkan "ruang" kedalam pikiran siswa, sehingga keruangan tersebut bukan lagi abstrak dalam benak siswa. Dalam memaksimalkan upaya meneliti kemampuan berpikir spasial tersebut digunakan model pembelajaran Problem Based Learning yang mendukung proses pengembangan kemampuan berpikir spasial. Maka dari itu peneliti akan meneliti secara eksperimenpengaruh model Problem Based Learning (PBL) menggunakan media informasi geospasial terhadap kemampuan berpikir spasial siswa kelas $\mathrm{X}$ IIS SMAN Bandarkedungmulyo Jombang.

\section{Metode}

Penelitian ini dilakukan menggunakan desain penelitian eksperimen semu (quasi experiment). Penelitian ini dilakukan untuk mengetahui pengaruh model Problem Based Learning menggunakan informasi geospasial (IG) terhadap kemampuan berpikir spasial siswa. 
Pada penelitian ini terdapat dua kelas dengan perlakuan yang berbeda. Kelas eksperimen diberikan perlakuan Problem Based Learning menggunakan informasi geospasial (IG), sedangkan kelas kontrol diberikan perlakuankelas konvensional. Penelitian yang dilakukan pada kedua kelas tersebut menggunakan rancangan Pretest Posttest Control Design.

Subjek penelitian ini adalah siswa kelas X IIS SMAN Bandarkedungmulyo. Jumlah kelas $\mathrm{X}$ IIS di SMAN Bandarkedungmulyo ada tiga kelas. Subjek penelitian diambil dari dua kelas berdasarkan rata-rata nilai ujian tengah semester mata pelajaran geografi yang setara. Dua kelas yang sesuai kriteria yaitu kelas X IIS 2 dan X IIS 3. Kelas X IIS 3 sebagai kelas kontrol yang akan menerapkan model pembelajaran konvensional sedangkan kelas X IIS 2 sebagai kelas eksperimen yang akan menerapkan model PBL menggunakan media IG.

Instrumen yang digunakan dalam penelitian berupa delapan soal uraian kemampuan berpikir spasial. Masing-masing soal mengandung komponen kemampuan berpikir spasial. Pembuatan soal tersebut berdasarkan taksonomi kemampuan berpikir spasial menurut Gersmehl dan Gersmehl (2011).

Data yang diperoleh untuk hipotesis pada penelitian eksperimen ini yaitu menggunakantest uraian berjumlah delapan butir soal dengan menggunakan pretest dan posttest pada siswa. Pretest diberikan untuk mengukur kemampuan awal siswa sebelum diberi perlakuan, kemudian posttest diberikan kepada siswa setelah mendapat perlakuan baik itu pada kelas eksperimen maupun pada kelas kontrol. Selanjutnya selisih dari hasil pretest dan posttest (gain score) inilah yang digunakan untuk menguji kebenaran hipotesis.

\section{Hasil dan Pembahasan}

Pada penelitian ini diperoleh suatu temuan bahwa model PBL menggunakan informasi geospasial berpengaruh terhadap kemampuan berpikir spasial siswa kelas X IIS di SMAN Bandarkedungmulyo Jombang. Pernyataan tersebut ditunjukkan dengan nilai rata-rata dari gain score kemampuan berpikir spasial kelas eksperimen yang lebih tinggi dibandingkan dengan kelas kontrol. Nilai rata-rata gain score kelas eksperimen 13,8 dan kelas kontrol 6,1. Selisih antara gain score kedua kelas tersebut yaitu 7,7dan hasil uji hipotesis penelitian menunjukkan nilaiSig. (2-tailed) 0,000 yang artinya ada perubahan setelah diberikan perlakuan. Berdasarkan hasil analisis tersebut dapat disimpulkan bahwa model PBL menggunakan informasi geospasial berpengaruh terhadap kemampuan berpikir spasial.

Tabel 1. Nilai rata-rata Pretest, Posttest, dan Gain Score Kemampuan Berpikir Spasial Kelas Eksperimen dan Kelas Kontrol

\begin{tabular}{llll}
\hline Kelas & Rata-rata Nilai Pretest & Rata-rata Nilai Posttest & Nilai Gain Score \\
\hline Eksperimen & 63,5 & 77,3 & 13,8 \\
Kontrol & 64,4 & 70,5 & 6,1 \\
\hline
\end{tabular}

Sumber: data diolah, 2019 


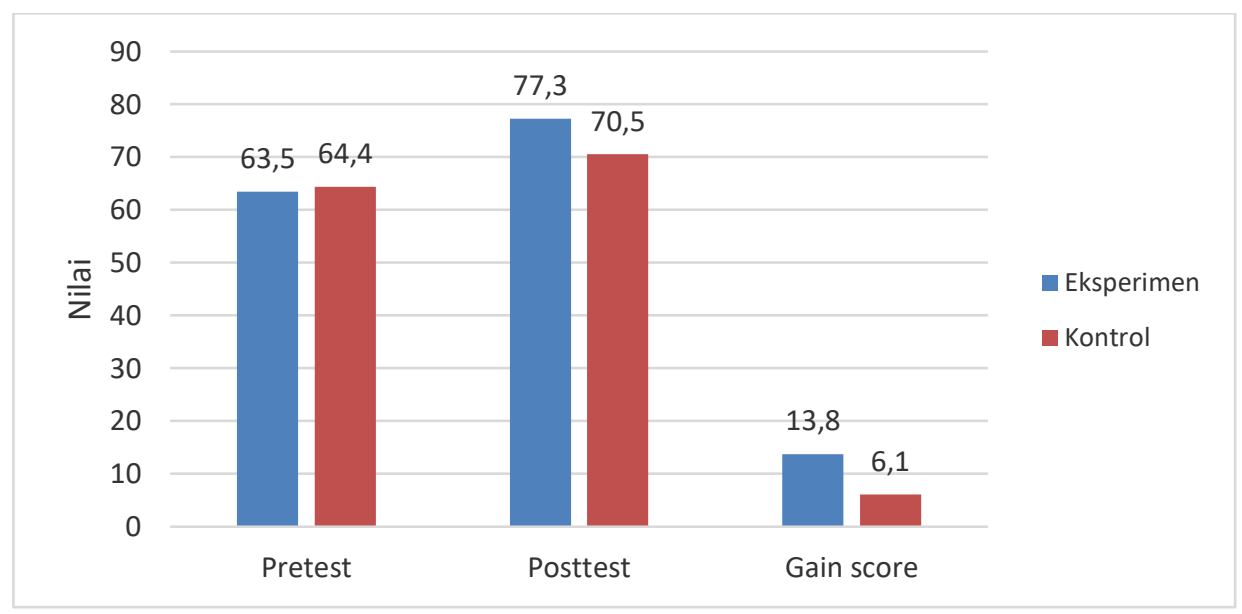

\section{Grafik 1. Perbandingan Nilai Rata-rata Pretest, Posttest, dan Gain ScoreKemampuan Berpikir Spasial Kelas Eksperimen dan Kelas Kontrol Sumber: data diolah, 2019}

Perbedaan kemampuan berpikir spasial siswa disebabkan perbedaan perlakuan yang diberikan saat proses pembelajaran. Pada kelas kontrol proses pembelajaran menggunakan model yang konvensional. Model konvensional mengedepankan peran guru sebagai sumber belajar, peran siswa hanya menunggu dan mendengarkan penjelasan guru tanpa berusaha menambah pengetahuan mereka sehingga siswa menjadi pasif. Proses pembelajaran konvensional tersebut kurang memberikan proses berpikir, sehingga siswa tidak memiliki kesempatan mengembangkan keterampilan berpikir spasial.

Tabel 2. Hasil Perhitungan Uji Hipotesis

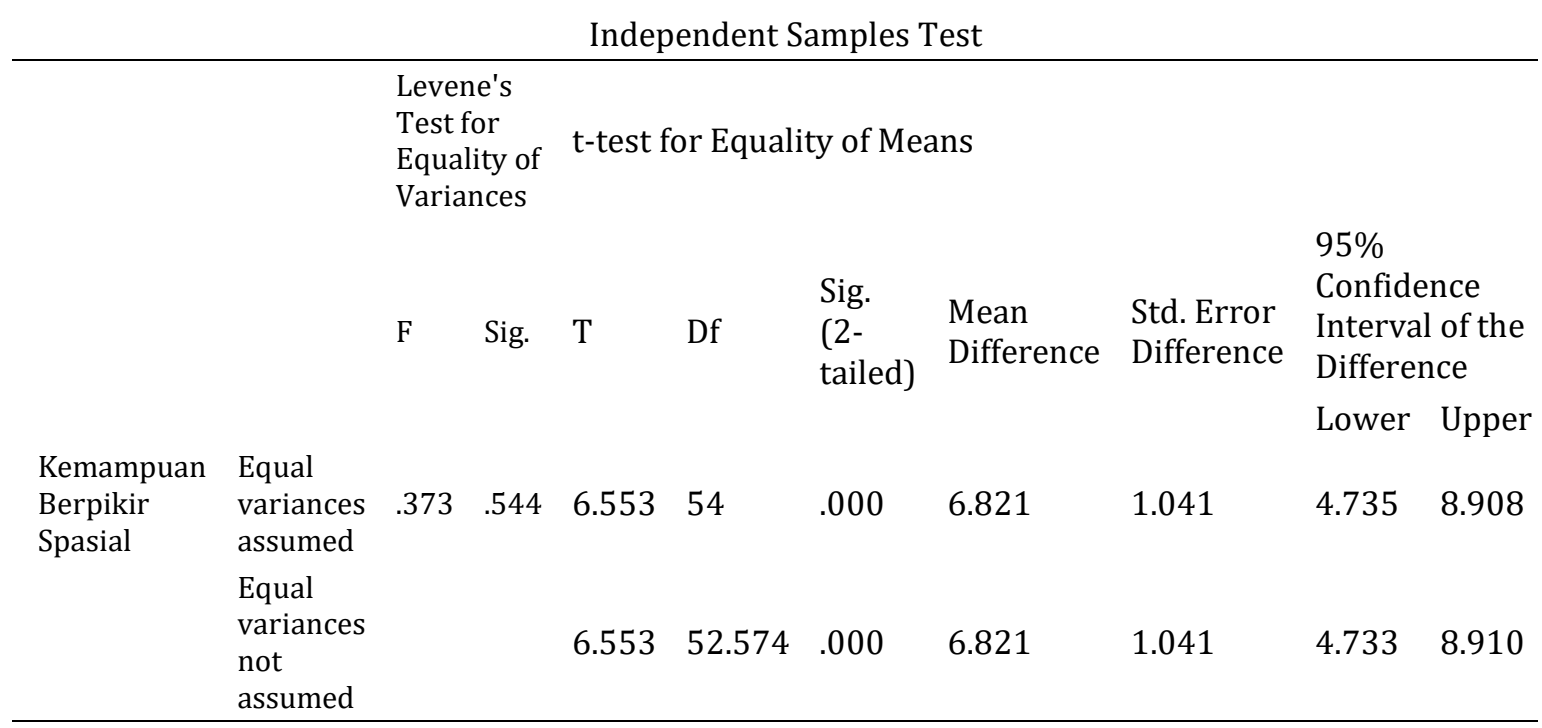

\section{Sumber: data diolah, 2019}

Model pembelajaran PBL menggunakan media informasi geospasial yang diterapkan pada kelas eksperimen dapat melatih siswa dalam mengembangkan kemampuan berpikir spasial. Hal ini disebabkan oleh faktor yang mendorong berkembangnya kemampuan berpikir spasial siswa saat diterapkan model tersebut. Adapun beberapa faktor tersebut menurut peneliti sebagai berikut. 
Faktor pertama, perbedaan aktivitas belajar. Perbedaan ini terdapat pada model pembelajaran yang diberikan. Kelas eksperimen diberikan perlakuan model PBL menggunakan media informasi geospasial. Model PBL menekankan proses belajar berpusat pada siswa. Model PBL aktif melibatkan siswa dalam pembelajaran. Siswa diajak untuk melakukan investigasi, eksplanasi dan pemecahan masalah yang bermula dari permasalahan yang nyata. Siswa terlibat aktif dalam proses pembelajaran sehingga informasi yang didapatkan bukan hanya dari guru semata melainkan dari kegiatan pembelajaran yang dilakukan bersama-sama.Penerapan model PBL melatih siswa membangun kerangka masalah, menyusun fakta, menganalisis data, dan menyusun argumentasi terkait pemecahan masalah, kemudian memecahkan masalah baik secara individual maupun kelompok. Dengan melakukan pembelajaran semacam itu, maka siswa terlibat aktif karena ada kegiatan yang dilakukan bersama-sama. Keterlibatan siswa secara aktif dalam pembelajaran merupakan cara yang efektif untuk menyerap setiap materi (Sembiring, 2008).

Pada kelas kontrol, perlakuan pada siswa menggunakan model konvensional. Model konvensional lebih didominasi oleh metode ceramah. Model konvensional ditandai dengan guru lebih banyak mengajarkan tentang konsep-konsep bukan kompetensi. Tujuan pembelajaran yang menggunakan model konvensional adalah siswa mengetahui sesuatu bukan siswa melakukan sesuatu. Pada proses pembelajaran siswa lebih banyak mendengarkan (Sukandi, 2003). Disini terlihat bahwa model konvensional didominasi oleh guru sebagai "pentransfer ilmu", sedangkan siswa lebih pasif sebagai "penerima ilmu". Hal ini sangat berpengaruh terhadap kebiasaan siswa yang hanya menunggu dan menerima informasi dari guru tanpa berusaha menambah pengetahuan mereka. Pembelajaran yang diterapkan melalui mendengarkan saja akan memberikan pemahaman informasi kepada siswa sebesar $20 \%$, persentase ini lebih sedikit dibandingkan dengan siswa melakukan sendiri aktivitas belajarnya melalui praktek (learning by doing) mendapat ketercapaian tujuan pembelajaran sebesar $90 \%$ (Warsono dan Hariyanto, 2012). Hal ini berdampak pada kemampuan siswa dalam memahami materi dan menggunakannya dalam memecahkan masalah, siswa akan kesulitan karena pengetahuan yang dimilikinya sebatas yang disampaikan guru. Selain itu siswa menjadi bosan karena pembelajaran kurang bervariatif. Beberapa siswa terlihat tidak memperhatikan saat pembelajaran. Hal ini mengakibatkan pembelajaran kurang efektif.

Faktor kedua, kemampuan berpikir spasial dapat dikembangkan dengan melakukan suatu latihan. Cara untuk melatih siswa dalam kemampuan berpikir spasial dengan cara merancang pembelajaran yang mendorong siswa untuk berpikir spasial. National Research Council (2006), menjelaskan kemampuan berpikir spasial sebagai hal pokok dan keterampilan yang dapat dipelajari secara formal dengan didukung alat, teknologi, dan kurikulum. Model PBL menggunakan media informasi geospasial memberikan kesempatan siswa melatih kemampuan berpikir spasial siswa melalui alat dan teknologi. Media informasi geospasial yang digunakan dalam penelitian ini yaitu peta. Peta mengandung informasi keruanganpermukaan bumi yang begitu banyak, misalnya; vegetasi, sungai, jalan, pemukiman dan topografi. Data yang ditampilkan pada peta dapat menjadi suatu informasi manakala pengguna peta mampu memahami simbol dan legenda pada peta sehingga informasi yang tersurat dapat dimengerti. Penggunaan peta sebagai media pembelajaran geospasial dapat mempermudah siswa mengenali keruangan objek dan lokasi yang akan dikaji. Jika siswa mampu mengenali objek ruang yang dikaji maka pencarian solusi dari sebuah permasalahan di suatu lokasi akan lebih mudah diputuskan. Penjelasan guru yang disertai peragaan dengan menggunakan peta akan 
memberikan gambaran yang lebih jelas mengenai konsep ruang yang dipelajari sehingga membantu pemahaman siswa.

Kemampuan berpikir spasial seseorang akan nampak saat menginterpretasi peta. Dengan mampu membaca peta berarti seseorang memiliki kemampuan berpikir spasial yang baik. Karena salah satu ciri dalam berpikir spasial adalah mampu mengenali dan menginterpretasi objek dengan baik seperti yang diungkapkan oleh American Association of Geographers (TT) bahwa kemampuan berpikir spasial berfungsi untuk menganalis dan menginterpretasikan hubungan suatu objek dalam suatu ruang "spatial thinking skills are an important set of competencies for examining the world around us. These skills enable the geographer to visualize and analyze spatial relationships between objects,such as location, distance, direction, shape, and pattern". Oleh karena itu, memberikan media peta pada siswa akan melatih mereka dalam menginterpretasi peta sehingga kemampuan berpikir spasial akan berkembang.

Faktor ketiga, kemampuan berpikir spasial dipengaruhi oleh adanya tahapan model PBL menggunakan media informasi geospasial. Tahapan dalam model PBL menggunakan media informasi geospasial yaitu 1) tahap orientasi siswa pada masalah, 2) mengorganisasikan siswa untuk belajar, 3) membimbing penyelidikan individual maupun kelompok, 4) mengembangkan dan menyajikan hasil karya, dan 5) menganalisis dan mengevaluasi proses pemecahan masalah. Pada tahap pertama, yakni orientasi siswa pada masalah. Pada tahap ini guru menyampaikan topik, tujuan, dan mengajukan sebuah fenomena atau cerita untuk memotivasi siswa. Guru memotivasi siswa untuk terlibat dalam pemecahan masalah dalam sebuah fenomena geosfer yang dipilih dalam lingkup sebuah wilayah. Pemecahan masalah yang dilakukan siswa akan lebih mudah jika siswa mengetahui kondisi keruangan wilayah tersebut. Oleh karena itu, diperlukan peta sebagai media untuk memberikan informasi keruangan dan keadaan geografis wilayah tersebut. Informasi yang didapatkan dari peta bisa digunakan siswa untuk mengenal wilayahnya secara geografis sehingga solusi yang ditemukan siswa juga sesuai dengan keadaan geografis wilayah tersebut. Dengan demikian, siswa menjadi lebih mudah dalam mengidentifikasi permasalahan tersebut.

Pada tahap kedua, yaitu mengorganisasikan siswa untuk belajar. Pada tahap ini, guru membantu siswa mendefinisikan dan mengorganisasikan tugas belajar yang berhubungan dengan masalah yang telah diorientasi, yaitu membantu siswa membentuk kelompok dan membantu siswa mengidentifikasi masalah, kemudian mencoba untuk membuat solusi atas masalah yang ditemukan tersebut. Pada tahap ini, siswa menentukan permasalahan tanah apa yang akan diselidiki, serta wilayah yang memiliki permasalahan tersebut. Dalam mengkaji permasalahan siswa diberi kebebasan sesuai dengan kondisi lingkungan yang ada. Siswa mengkaji permasalahan yang mereka temukan di lapangan terkait dengan permasalahan tanah. Salah satu hasil rumusan masalah kelompok di kelas eksperimen adalah sebagai berikut.

“(1) Mengapa terjadi alih fungsi lahan pertanian menjadi lahan pemukiman di Ds. Kayen, Kec. Bandarkedungmulyo?, (2) Apa faktor yang menyebabkan alih fungsi lahan pertanian menjadi lahan pemukiman penduduk?, dan (3) Apa dampak yang ditimbulkan dari adanya alih fungsi lahan pertanian menjadi lahan pemukiman?, (4) Bagaimana upaya yang dilakukan untuk mengatasi permasalahan tersebut?" 
Sebagian besar kelompok mampu merumuskan masalah dengan baik sesuai dengan topik permasalahan yang dibahas. Siswa aktif secara berkelompok dalam merumuskan masalah. Melalui kegiatan merumuskan masalah dapat meningkatkan keaktifan siswa dalam pembelajaran. Hal tersebut dikarenakan dalam merumuskan masalah siswa dituntut menemukan solusi dari permasalahan tersebut. Kemampuan berpikir siswa berkembang ketika siswa dihadapkan dengan permasalahan secara nyata di lapangan.

Tahap ketiga yaitu membimbing penyelidikan individual maupun kelompok. Pada tahap ini, guru mendorong siswa untuk mengumpulkan informasi sebanyak-banyaknya mengenai permasalahan yang sudah ditentukan bersama kelompok, melaksanakan penyelidikan di lapangan, menciptakan dan mengembangkan ide mereka sendiri untuk mendapatkan solusi pemecahan masalah. Dalam mengumpulkan informasi, siswa melakukan proses penyelidikan. Siswa melakukan penyelidikan terhadap objek penelitiannya dengan melakukan pengamatan langsung dan wawancara pada narasumber yang berkaitan dengan permasalahan mereka. Melalui kegiatan penyelidikan di lapangan, siswa mengamati objek kajian atau dalam konteks ini adalah wilayah yang mereka kaji sebagai sebuah objek penelitian yang mana wilayah tersebut memberikan informasi secara nyata di lapangan mengenai informasi keruangan. Proses penyelidikan di lapangan memberikan kesempatan siswa berinteraksi dengan ruang, sehingga dapat melatih kemampuan berpikir spasial siswa.Saat di lapangan, siswa mendapatkan informasi keruangan yang didapat dari hasil proses berpikir spasial. Siswa melatih spatial influences (auras)mereka. Spatialinfluences adalah pengaruh letak suatu tempat dapat mempengaruhi tempat di sekitarnya. Salah satu cara melatih spatial influences siswa yaitu melalui wawancara yang dilakukan siswa. Siswa mencari tahu dampak dari adanya permasalahan tanah terhadap masyarakat di lingkungan sekitar.Setelah itu siswa belajar menggolongkan tempat-tempat yang terdampak oleh permasalahan tersebut. Salah satu hasil dari wawancara dari kelompok yaitu sebagai berikut.

"Alih fungsi lahan dari lahan pertanian menjadi lahan perumahan (pemukiman) yang terjadi di Desa Kayen, Kec. Bandarkedungmulyo memberikan dampak bagi petani. Irigasi menjadi berkurang untuk sawah dikarenakan banyak digunakan oleh kebutuhan rumah tangga. Produktivitas padi berkurang, sehingga kebutuhan beras disokong dari wilayah lain sedangkan permintaan beras sangat banyak, sehingga petani tidak dapat memenuhi permintaan tersebut. Akan tetapi selain itu, dampak adanya perumahan membuat harga jual tanah menjadi tinggi, sehingga menguntungkan juga bagi masyarakat yang memiliki tanah disana". Menggolongkan tempat-tempat yang memiliki kesamaan dan mengklasifikasikan sebagai satu kesatuan termasuk melatih siswa dalam spatial groups (regions) sesuai indikator kemampuan berpikir spasial. Dapat disimpulkan bahwa penyelidikan yang dilakukan di lapangan oleh siswa dapat melatih dan mengembangkan kemampuan berpikir spasial mereka.

Tahap keempat yaitu mengembangkan dan menyajikan hasil karya. Pada tahap ini guru membantu siswa dalam menganalisis data yang telah terkumpul pada tahap sebelumnya. Siswa memberi argumen terhadap jawaban pemecahan masalah sesuai informasi atau data yang di peroleh, baik data yang didapatkan dari internet maupun dari lapangan. Siswa menguraikan jawaban dari rumusan masalah yang telah dibuat kemudian menganalisis data dengan menghubungkan pada temuan yang telah diperoleh di lapangan dengan teori. Siswa bersama kelompok mencari solusi dari permasalahan yang sudah mereka kaji kemudian menuliskannya dalam sebuah laporan dan dipersentasikan kepada teman-teman sekelasnya. 
Dalam memecahkan permasalahan, siswa telah menggunakan kemampuan berpikir spasial mereka.

Tahap kelima, menganalisis dan mengevaluasi proses pemecahan masalah. Guru membantu siswa untuk melakukan refleksi terhadap hasil penyelidikannya serta prosesproses pembelajaran yang telah dilakukan. Analisis dan evaluasi proses pemecahan masalah dilakukan untuk membantu siswa meninjau kembali proses mereka sendiri dan keterampilan penyelidikan dan intelektual yang mereka gunakan. Siswa akan merekonstruksi pemikiran dan aktivitas yang telah mereka lakukan selama kegiatan belajar menggunakan model PBL menggunakan IG. Setelah selesai pembelajaran, guru memberikan penguatan sehingga siswa memiliki konsep yang bulat tentang kompetensi dasar yang dipelajari.

Tahapan dalam model Problem Based Learning menggunakan IG berpengaruh terhadap kemampuan berpikir spasial. Model Problem Based Learning menggunakan IG melatih siswa memecahkan masalah, mengambil keputusan, dan mengembangkan kemampuan siswa untuk meneliti. Peran model PBL dalam mengembangkan kemampuan berpikir spasial tidak terlepas dari keunggulan yang dimiliki model PBL. Keunggulan dari model PBL menggunakan IG yaitu memancing rasa ingin tahu sehingga siswa lebih antusias dan proses pembelajaran lebih aktif. Antusias siswa muncul karena adanya media pembelajaran informasi geospasial (IG) yang membuat siswa melihat keruangan wilayah mereka yang selama ini tidak diketahui, misalnya jenis-jenis tanah di Kab. Jombang. Penggunaan peta jenis tanah menarik perhatian siswa sehingga antusias mereka terhadap pembelajaran lebih tinggi maka guru menjadi lebih mudah mengorganisir pembelajaran. Proses belajar mengajar dapat berhasil dengan baik jika segala sesuatu yang dapat digunakan untuk menyampaikan pesan atau informasi dalam proses belajar mengajar sehingga dapat merangsang perhatian dan minat siswa dengan menggunakan media pembelajaran.Keterlibatan siswa secara aktif juga ditunjukkan oleh antusias siswa dalam mencari informasi dalam memecahkan permasalahan tanah di sekitar mereka.

Dalam penelitian ini secara garis besar pelaksanaan model PBL menggunakan IG sudah dapat dilaksanakan dengan baik. Namun, masih terdapat beberapa kendala. Kendala yang ditemui yaitu pada pertemuan pertama, siswa masih belum terbiasa dengan model PBL, siswa masih terbiasa dengan mendapatkan informasi yang diperoleh dari guru sebagai narasumber utama. Dari segi waktu, saat pelaksanaan kegiatan pembelajaran waktunya sesuai dengan yang direncanakan, tetapi diskusi memerlukan waktu yang lebih panjang.

Penelitian empiris yang terkait pengaruh model PBL telah banyak dilakukan pada mata pelajaran geografi. Akan tetapi yang menggunakan model PBL menggunakan media IG untuk mengukur kemampuan berpikir spasial belum pernah dijumpai. Penelitian mengenai model PBL juga dilakukan oleh Susetyo (2016) berjudul Pengaruh Pembelajaran Problem Based Learning berbasis Outdoor AdventureEducation terhadap Kecerdasan Spasial Geografi dan Berfikir Tingkat Tinggi. Penelitian ini menyimpulkan bahwa PBL berbasis outdoor study berpengaruh secara signifikan terhadap kecerdasan spasial dan berpikir tingkat tinggi mahasiswa di kelas ekserimen lebih tinggi dibandingkan dengan kelas kontrol. Penelitian model PBL berikutnya juga dilakukan oleh Alifia (2016) mengenai Pengaruh Model Problem Based Learning terhadap Kemampuan Berpikir Spasial Siswa SMA kelas XI IIS di SMAN 1 Kepanjen. Dalam penelitiannya, terungkap bahwa model PBL berpengaruh secara signifikan dalam meningkatkan kemampuan berpikir spasial siswa di kelas XI IIS di SMAN 1 Kepanjen tersebut. 
Hasil temuan diatas dapat disimpulkan bahwa model Problem Based Learning menggunakan IG berpengaruh terhadap kemampuan berpikir spasial. Temuan ini semakin memberikan penguatan terhadap temuan-temuan sebelumnya. Penguatan ini berupa kelebihan model PBL menggunakan IG dalam meningkatkan kemampuan berpikir spasial siswa jika dibandingkan dengan penggunaan model konvensional.

\section{Simpulan}

\subsection{Simpulan}

Berdasarkan rumusan masalah dan hasil penelitian yang telah diperoleh, maka kesimpulan dalam penelitian ini adalah "model Problem Based Learning menggunakan Informasi Geospasial terhadap kemampuan berpikir spasial siswa kelas X IIS di SMAN Bandarkedungmulyo Jombang". Dengan kata lain, kemampuan berpikir spasial kelas yang menggunakan model Problem Based Learning menggunakan Informasi Geospasial memperoleh rata-rata lebih tinggi dari kelas yang tidak menggunakan model tersebut.

\subsection{Saran}

Bagi guru disarankan untuk menggunakan model Problem Based Learning(PBL) menggunakan informasi geospasial pada mata pelajaran geografi. Model Problem Based Learning menggunakan informasi geospasial pada penelitian ini membuktikan bahwa kelas yang menggunakan model tersebut memiliki pengaruh terhadap kemampuan berpikir spasial siswa. Jika menerapkan model PBL menggunakan IG, guru diharapkan terlebih dahulu untuk membuat rencana pelaksanaan pembelajaran (RPP). Pada RPP guru perlu menambahkan sintak-sintak model pada kegiatan ini meliputi: orientasi siswa pada masalah, mengorganisasikan siswa untuk belajar, mendukung kelompok melakukan penyelidikan, mengembangkan dan mempersentasikan karya dan mengevaluasi masalah (refleksi). Guru juga perlu memperhatikan alokasi waktu yang digunakan dalam setiap pembelajaran agar setiap tahapan dapat terlaksana dengan baik. Pada tahap mengorganisasikan siswa untuk kelompok, guru sebaiknya memberikan bimbingan, arahan, maupun petunjuk kepada siswa. Selain itu, jika berkelompok, guru harus memperhatikan keaktifan masing-masing anggota kelompok, sehingga seluruh siswa benar-benar terlibat aktif dalam setiap tahapan. Pada tahap mendukung kelompok melakukan penyelidikan, guru perlu memastikan kesiapan setiap kelompok sebelum melakukan penyelidikan ke lapangan sehingga siswa paham apa yang akan mereka lakukan saat dilapangan. Bagi peneliti lanjut yang ingin melakukan penelitian serupa disarankan untuk mempersiapkan data informasi geospasial yang lebih beragam, bisa berupa peta tematik, grafik maupun tabel. Apabila ingin menggunakan variabel terikat yang serupa maka disarankan untuk menyusun rencana pelaksanaan pembelajaran yang dapat melatih setiap indikator kemampuan berpikir spasial dengan baik serta pemberian alokasi waktu yang tepat. Selain itu, peneliti lanjut dapat melakukan penelitian menggunakan materi pembelajaran yang berbeda.

\section{Daftar Rujukan}

Alifia, Hidayatul. (2016). Pengaruh Model Problem Based Learning terhadap Kemampuan Berpikir Spasial Siswa Kelas XI IIS SMAN 1 Kepanjen (online), (http://karyailmiah.um.ac.id /index.php /Geografi/article /view/55520), diakses 20 Januari 2018.

American Association of Geographers. TT. Introducing Spatial Thinking Skills Across The Curriculum (online) (http://www.aag.org/galleries/tgmg-files/spatial_thinking_history_lesson.pdf), diakses 15 Juli 2018. 
Bednarz, Robert S dan Jongwon Lee. (2011). The Components of Spatial Thinking: Empirical Evidence (online),(https://www.researchgate.net/publication/251714226_The_components_of_spatial_thinkin g_Empirical_evidence), diakses 21 Juni 2018.

Committee on Support for Thinking Spatially. (2006). Learning do Think Spatially. Washington. D.C: The National Academies Press.

Gersmehl, Philip J dan Carol A. Gersmehl. (2011). Spatial Thinking: Where Pedagogy Meets Neurocsience (online), (http://oaji.net/articles/2014/457-1404985920.pdf), diakses 13 Juni 2018.

Golledge. (2002). The Nature of Geographic Knowledge. Annals of the Association of American Geographers, 92(1), 1-14. (online), diakses 17 Januari 2018.

Goodchild, M. (2006). The Fourth R? Rethinking GIS Education, ArcNews Fall $2006 . \quad$ (online), (http://www.esri.com/news/arcnews/fall06articles/the-fourth-r.html), diakses 2 Februari 2018.

Lee, J dan Robert Bednarz. (2009). Effect of GIS Learning on Spatial Thinking, Journal of Geography in Higher Education 33:2, 183-198, DOI: 10.1080/0309826080227671(online), diakses 8 Agustus 2018.

National Research Council. (2006). Learning to think spatially: GIS as a support system in the K-12 curriculum. National Academies Press.

Sukandi, Ujang. (2003). Belajar Aktif dan Terpadu. Surabaya: Duta Graha Pustaka.

Susetyo, Bigharta Bekti. (2017). Pengaruh Pembelajaran Problem Based Learning Berbasis Outdoor Adventure Education Terhadap Kecerdasan Spasial. Jurnal Pendidikan: Teori, Penelitian, dan Pengembangan Volume: 2 Nomor: 12 Bulan Desember Tahun 2017 Halaman: 1669-1675 (online), (http://journal.um.ac.id/index .php/jptpp/article/download/10326/4957), diakses 12 Januari 2018.

Trianto. (2009). Mendesain Model Pembelajaran Inofatif-Progresif. Jakarta: Kencana.

Warsono dan Hariyanto. (2012). Pembelajaran Aktif Teori dan Asesmen. Surabaya: Remaja Rosdakarya. 